\title{
36 \\ Consumer protection: A case of successful regulation
}

\author{
John TD Wood
}

\section{Introduction}

In The Wealth of Nations, the philosopher and economist Adam Smith expounded his view that:

Consumption is the sole end and purpose of all production; and the interest of the producer ought to be attended to, only so far as it may be necessary for promoting that of the consumer. (Smith 1776: Book IV, Chapter VIII, vol. ii, para. 49)

He was making an important contribution to how we should view the market when we consider key aspects of consumer protection, and added to a long history of practical protection.

\section{Background}

From the time of the earliest recorded codification of laws, those of King Hammurabi of Babylon (1795-50 BC), we find examples of consideration of consumer protection measures: matters dealing with fairness in the marketplace and ensuring that measurements are correct and goods safe. Thus, the Code of Hammurabi contained the following examples: 
104. If a merchant give an agent corn, wool, oil, or any other goods to transport, the agent shall give a receipt for the amount, and compensate the merchant therefor. Then he shall obtain a receipt from the merchant for the money that he gives the merchant.

108. If a tavern-keeper (feminine) does not accept corn according to gross weight in payment of drink, but takes money, and the price of the drink is less than that of the corn, she shall be convicted and thrown into the water.

229. If a builder build a house for some one, and does not construct it properly, and the house which he built fall in and kill its owner, then that builder shall be put to death.

233. If a builder build a house for some one, even though he has not yet completed it; if then the walls seem toppling, the builder must make the walls solid from his own means. ${ }^{1}$

Needless to say, consumer protection can, and has, appeared in many guises and has taken many different forms over the centuries and decades. Governments, alerted to practices considered injurious to the health, safety or economic welfare of the community, have, from time to time, been sufficiently roused to bring in legislative measures to cure the ill. Sometimes they have even been moved to prevent the ailment arising.

There are, then, consumer protection measures in statutes that deal with explosives and other hazardous substances, in the controls for therapeutic goods, in building codes, in the regulation of supply and use of chemicals, in the supply of energy, in requirements for the incorporation of entities, in road traffic rules, in vehicle design rules, and so on.

Throughout the world, various of these have, from time to time, been the principal focus for consumer concern. In developing economies, consumer attention is frequently given simply to the basics of living: adequate and clean drinking water, weatherproof (and often disasterproof) and safe shelter and adequate and uncontaminated food.

In the contemporary world, discussion of government involvement in consumer affairs tends to relate to:

1 As set out in the Code of Hammurabi (available at: commonlaw.com/home/legal-history-andphilosophy/code-of-hammurabi; Johns 1987). 
- the mandating of fair-trading practices in the marketplace and prohibition of anticompetitive conduct

- regulation of the supply and use of hazardous goods and services

- establishment of minimum or mandatory standards for goods and services

- fiduciary oversight and regulation of the practices of suppliers of economic and financial services

- the regulation of telecommunication and energy services

- maintenance of a system of weights and measures

- requirements for transparency and for information disclosure in consumer transactions

- the control of fit and proper persons to carry out commercial activities

- harmonisation of international standards and practices.

Illustrative of developments in consumer protection over the years in Australia and elsewhere are the following sectors.

\section{Weights and measures}

This has been one of the oldest areas of market control. The checking of weighing devices-or implements and vessels for measuring volumes of oil, wine and grain - goes back a very long time. Beer measures became especially important, which is why standard-sized drinking vessels came into use-for example, English 'pewters' and German 'steins'. The United Kingdom gained a Weight and Measures Act in 1795, which was duplicated in New South Wales in 1832. This legislation, in a more contemporary form, first came into force at the time of World War I-for example, the Weights and Measures Act 1915 (Q1d).

To recognise the national importance given to weights and measurement, the Weights and Measures (National Standards) Act 1948 was enacted by the Federal Parliament and the National Standards Commission established. 
In more recent times, the needs of a national marketplace have been recognised, so that matters dealing with everything from units of measurement through to packaging and labelling are dealt with through uniform trade measurement legislation (for example, see the Trade Measurement Act 1993 (SA)).

\section{Public health and food}

Control of medicines became essential following the growth of patent medicine sellers-the 'snake oil merchants'-at the turn of the century, and as more scientific knowledge became available about the effects of some of the cures that had been merrily dispensed by Victorian medicos, such as laudanum and arsenic.

Similarly, the growth of food processing plants and food preparation places, with the inevitable increase in food poisoning, led to food hygiene rules and inspectors. The Public Health Act 1902 (NSW) covered the sale of unadulterated food, food standards, pollution, fraudulent ingredient labelling and injurious food. Subsequently, the companion Pure Food Act 1908 established rules and inspection regimes.

In both cases, it was concern with contamination and adulteration and, in the case of drugs, deceptive sales practices, which led to the legislative action. These statutes came into being as much to protect reputable businesses from disreputable competitors as to look after the interests of consumers.

The Australian legislative models, again, drew on overseas precedent, in this case the UK Sale of Food and Drugs Act 1875 and the US Food and Drugs Act 1906. Interestingly, given the then preoccupation of many of the male citizens of the country, one of the first pieces of legislation protecting the 'purity' of products was the Liquor Adulteration Act 1855 (Q1d).

\section{Dangerous people!}

The first statutory schemes to protect consumers were designed to prevent undesirable people from carrying out various occupations. Hence, the Hawkers and Pedlars Act 1849 (Q1d); the Pawnbrokers Act 1857 (Tas.); the Landlords and Tenants Act 1899 (NSW); 
the Book Purchasers Protection Act 1899 (NSW) (an early example of regulation of door-to-door sales); the Second-hand Dealers and Collectors Act 1906 (ACT); the Money-lenders Act 1912 (WA); and the Auctioneers and Agents Act 1941 (NSW). Because of profiteering due to shortages in some areas following World War II, and as a means of controlling inflation, price control legislation was also introduced (for example, the Prices Act 1948 (SA)). This form of regulation was extended to some individual products at different times-for example, beer and petrol prices in 1981 (Fuel Prices Regulation Act 1981 (Vic.)) and, most recently, by Part VB of the Trade Practices Act 1974 (Cth), to protect consumers against exploitation following the introduction of a new tax system.

Another form of regulation also entered the statute books with the stated intention of protecting the consumers of professional services, although it was really more about safeguarding the interests of those already accredited, from competition. Thus, legal practitioners (Legal Practitioners Act 1881 (Q1d)), veterinary surgeons (Veterinary Act 1918 (Tas.)), architects (Architects Act 1921 (NSW)), medical practitioners (Medical Act 1894 (WA)), dentists (Dentists Act 1919 (Tas.)) and accountants (Public Accountants Registration Act 1945 (NSW)) received their own protection.

In recent times, this form of licensing was more broadly used to require certain minimum qualifications for entry into other occupations where it was considered that either disreputable practices had occurred or the consumer was potentially at risk if professional standards were not maintained or proof of good behaviour not required. Thus, in various jurisdictions, we saw regulation of activities ranging from those of psychologists to those of travel agents and those of financial advisers and planners.

\section{Building}

Local government controlled house building, and the development of regulation in the form of ordinances developed rapidly in Australia because of the very high levels of building.

After World War II, these controls became as concerned with matters affecting the health of occupants—such as ventilation, light penetration, plumbing, sewerage and drainage — as with the strength of the building's 
structure. More recently, standards relating to energy efficiency and conservation have been developed to ensure the sustainability of building projects (see van der Heijden, Chapter 41, this volume).

\section{Post-sale consumer protection}

Concern about the inequality of bargaining power of parties in the marketplace gave rise to the first specific consumer protection laws, the sale of goods legislation of the late nineteenth century (for example, the UK Sale of Goods Act 1893), which spread through the British Empire into the early days of the twentieth century and was the origin of all sale of goods legislation in the Australian states and territories, and a key component of the consumer protection provisions of the Trade Practices Act 1974 (Cth).

\section{Defective products}

The liability of manufacturers for their defective products was first recognised by the courts in the United States in 1916 when, in relation to the rapidly booming automobile industry, strict liability for mistakes in the manufacturing process was imposed on the makers of Buick cars. In the English law, it was the famous case of the mouse in the ginger beer bottle (Donoghue v Stevenson) in 1932 that established the liability of manufacturers, and which was followed in this country until the 1977 amendments to the Trade Practices Act 1974. These were subsequently enhanced by the product liability provisions enacted as Part VA of the Act.

\section{The new affluence and debt}

As the gigantic manufacturing apparatus that had been brought into being to supply goods for the war effort during World War II was turned back to civil production, the affluent West saw a boom in the production of consumer goods. Coupled with the technological revolution that the war had also inspired, a new range and variety of products rapidly emerged into the consumer marketplace. Many of these were far more complex in engineering and design than their precursors, and, because of mass production techniques, far more accessible to a broad spectrum of the community. 
The rapid expansion of commercial radio, with its enticing advertisements, and the advent of television provided further impetus to consumerism's rapid advance.

To complement this new and burgeoning consumer market came new methods of financing purchases. Following the Depression, the domestic market had boomed and, with banks retaining conservative lending practices and generally inaccessible to the man (and certainly the woman) in the street, consumers got caught up in schemes offering payment by instalment programs, called hire purchase. In some cases, the interest rates and practices of the companies offering this 'service' were unconscionable, with harsh contracts, extortion and inequality between the parties. As a result, a form of regulation was introduced by the various hire purchase laws of the late 1930s and early 1940s. See, for example, the Hire Purchase Agreements Act 1941 (NSW). The Credit Sales Agreements Act 1957 (NSW), covering the purchase of goods on credit from retail stores, and the Hire Purchase Act 1960 (NSW), dealing with finance obtained from credit providers for goods that were not owned until the entire sum was paid off, followed.

As access to a range of financial services widened, with finance companies (often owned by the major banks) being established and new products developed, the first attempts at achieving nationally uniform credit legislation began in 1972-not finally succeeding until 22 years later. Finally, recognition was given to the importance of national regulation with the introduction of the National Consumer Credit Protection Act 2009 (Cth).

\section{Kennedy, Moloney, Hutchison and Nader and the era of the consumer activists}

US President John F Kennedy announced on 15 March 1962, in a directive to the Consumer Advisory Council, that consumers had some basic rights-namely:

- the right to safety

- the right to be informed

- the right to choose

- the right to be heard. 
He also forecast the establishment for the first time of an Office of Consumer Affairs. It was President Johnson who ultimately carried this out, and who also established the position of Presidential Adviser on Consumer Affairs, the first occupant of which was the labour activist Esther Petersen.

Later in that same year, an extremely influential report (Final Report of the Committee on Consumer Protection) was published in the United Kingdom. Known as the Molony Report after the chair of the committee that produced it, the report contained some 2,000 proposals and recommendations following its examination of significant areas of consumer need and of existing legislation, as well as of the need for further protection of the consuming public.

The major recommendations were:

- the establishment of a Consumer Council to 'ascertain and review the problems experienced by the consumer and to devise and advance the means of resolving them' (Moloney 1962)

- the revision of hire purchase legislation

- the consolidation and revision of the merchandise marks legislation

- the amendment of the Sale of Goods Act 1933

- the registration of Seals of Approval, and the amendment, in a number of minor respects, of the Trade Marks Act 1938 (Moloney 1962).

Meanwhile, in Australia, the first female member of the West Australian Legislative Council, Ruby Hutchison, initiated the Australian Consumers' Association at a meeting in Sydney Town Hall in 1959. Established as a non-profit independent organisation undertaking product testing, it saw itself as a response to the ever-growing consumer complaints about poor-quality goods and services.

In 1965, Ralph Nader published his definitive book on a corporation's (General Motors) lack of concern for its consumers (and its critics), Unsafe at Any Speed. His work in establishing specific-purpose consumer groups (popularly known as 'Nader's Raiders') in the United States was paralleled in Australia with a plethora of groups at the state and territory level over the next 20 years that covered fields from health care to credit counselling, and from product safety to food and nutrition. 


\section{The consumer protection acts}

All governments in Australia had their attention drawn to the safety of a wide range of consumer products following Nader's campaigns, the establishment by the US Federal Government of the Product Safety Commission and the results from a growing number of product tests carried out by the Australian Consumers' Association. The first government response was in Victoria, where the Consumer Protection Council, to advise the government on consumer protection issues, was established in 1965. It was, however, the NSW Consumer Protection Act 1969 that became the general model for the rest of the nation and established both the Consumer Affairs Council and the Consumer Affairs Bureau under the Commissioner for Consumer Affairs. The bureau's primary responsibility was to advise consumers and handle their complaints- the first time a government had provided such a service.

When considering why it was this particular era (1965-75) that finally saw the advent of government consumer affairs agencies and widereaching consumer protection legislation, a NSW Department of Consumer Affairs' publication in 1987 suggested the following factors:

- The rapidly increasing VARIETY of goods and services which modern technology made available and which became increasingly difficult for the consumer to evaluate;

- The growing size and complexity of the production and distribution system which placed the buyer at an increasing distance, both physically and psychologically, from the seller;

- The high level of SOPHISTICATION IN MARKETING AND SELLING PRACTICES in advertising and other forms of promotion;

- The REMOVAL OF THE PERSONAL ELEMENT from the buyer/seller relationship as a result of large shopping centres and supermarkets, mass-marketing methods and the consumer's greatly increased mobility;

- The PRE-PACKAGING OF GOODS which again made it difficult for consumers to assess what they were getting in terms of value for money and operational ability;

- The increasingly COMPLEX TERMS AND CONDITIONS on which goods and services were sold;

- The many and varied forms of CONSUMER CREDIT and their widespread availability; 
- The CONFLICT OF INTERESTS between standard business practices and consumers' needs;

- The increasing availability of RENTAL SCHEMES, as against direct purchase, for a wide range of goods;

- The growth of LARGE CORPORATIONS, MULTINATIONAL COMPANIES AND MONOPOLIES which often placed the consumer at a disadvantage in the marketplace in terms of bargaining power;

- POOR ACCESS TO LITIGATION AND REDRESS-the court system being too costly for the average consumer to gain redress for problems with everyday goods and services. This added yet another layer to the general sense of powerlessness. (NSW Department of Consumer Affairs 1987).

\section{The national perspective}

With the advent of the Whitlam Labor Government in 1972, consumer affairs, for the first time, was given national attention. The outstanding product of this was the Trade Practices Act 1974 (TPA). Considered by many internationally as the best model of consumer legislation, its architect, then Attorney-General, Lionel Murphy, drew, as was his wont, on the best of US and English law and his creative ideas and those of his advisers. The Act amalgamated a strict regime for dealing with restrictive trade practices (vastly improving provisions contained in an earlier Act) ${ }^{2}$ with groundbreaking consumer protection provisions. He described the legislation's purpose thus:

In consumer transactions, unfair practices are widespread. The existing law is still founded on the principle known as caveat emptor-meaning 'let the buyer beware'. That principle may have been appropriate for transactions conducted in village markets. It has ceased to be appropriate as a general rule. Now the marketing of goods and services is conducted on an organized basis and by trained business executives. The untrained consumer is no match for the businessman who attempts to persuade the consumer to buy goods or services on terms and conditions suitable to the vendor. The consumer needs protection by the law and this Bill will provide such protection. ${ }^{3}$

2 Restrictive Trade Practices Act 1965 (Cth).

3 Senator the Hon. LK Murphy QC (1973), CPD Senate, vol. 57: 1013-14. 
A consumer affairs division was also established to provide policy advice to the first Federal Minister for Consumer Affairs. ${ }^{4}$ With the Act coming into force and with the Trade Practices Commission engaging in active enforcement, the consumer protection landscape in Australia was changed forever.

This was nowhere better demonstrated than in the landmark prosecution of the Sharp Corporation of Australia by the Trade Practices Commission for false and misleading advertising. ${ }^{5}$ The Federal Court fined Sharp $\$ 10,000$ for each of 10 counts - a total of $\$ 100,000$, which was a huge sum for the time and one that sent a very strong message through corporate Australia, the advertising industry and the media.

\section{What the statutes protect}

The consumer protection laws adopted over time by the federal, state and territory governments deal with the following matters: ${ }^{6}$

- prohibition or regulation of undesirable or unfair practices

- prescription of terms to be implied into contracts made with consumers

- prescription of standards of goods and services to be provided to consumers

- regulation of dangerous goods and services

- protection of public health and safety

- establishment of bodies to receive complaints from consumers, to investigate those complaints and to take action (including, if necessary, action in the courts) to rectify any justified complaints

- establishment of machinery to promote the education of consumers

- licensing and ongoing regulation of the types of people or organisations who may be permitted to supply certain types of goods and services to consumers.

4 The first Federal Minister for Consumer Affairs was the Hon. Bill Morrison MP, who was Minister for Science and Consumer Affairs. He was succeeded by the Hon. Clyde Cameron MP.

$5 \quad$ Hartnell $v$ Sharp Corporation of Aust. Ltd (1975) 5 ALR 493.

6 The list builds on an original one in Goldring and Maher (1976). 


\section{International action}

In 1960, the International Organisation of Consumers Unions (IOCU) was formed by the consumer organisations of Australia, the United States, the United Kingdom, Belgium and the Netherlands that believed they could increase their strength by building networks across national borders.

The IOCU grew rapidly over the next few decades and, in 1995, it was renamed Consumers International (CI). Currently, it has more than 240 member bodies from 120 countries. It also has regional offices in Africa, Asia and the Pacific and Latin America and the Caribbean; subregional offices for West and Central Africa and for Central America; and a Programme for Developed Economies and Economies in Transition; as well as its head office in London.

The IOCU took the four consumer rights enunciated by President Kennedy in 1962 - the rights to safety, to be informed, to choose and to be heard - and added four of its own:

- the right to redress

- the right to consumer education

- the right to a healthy environment

- the right to the satisfaction of basic needs.

The IOCU then set about trying to get some form of international recognition of these rights, to stimulate much wider adoption by national governments of effective consumer protection laws. The late 1970s and early 1980s gave evidence of the growing power of multinational corporations and the limitations on national governments in trying to gain redress for consumers if such corporations offended.

Consequently, the IOCU also worked very hard to obtain United Nations (UN) acceptance of a draft code of conduct for transnational corporations. While this campaign ultimately failed, much of its work ended up in codes adopted by some international business groups and in the rules of the UN Conference on Trade and Development (UNCTAD).

However, its lobbying efforts, particularly those of Anwar Fazal, then director of the Regional Office for Asia and the Pacific and a former IOCU president, and Esther Petersen, the IOCU's Special Representative to the United Nations, inspired some progressive administrators within 
national governments to support another initiative. Eventually, despite some vigorous opposition from the United States, the UN Guidelines for Consumer Protection (UNGCP) were adopted by the General Assembly on 9 April 1985 (UN 1985).

Australia readily accepted its international responsibilities in relation to the guidelines and, in February 1990, sponsored a workshop for countries from the South Pacific, which recommended the establishment of a South Pacific Consumer Protection Programme (SPCPP). At a UN regional seminar on consumer protection for Asia and the Pacific in June 1990, jointly sponsored by Australia, the Australian Government announced its funding of the SPCPP through the IOCU's Regional Office for Asia and the Pacific, then in Penang, Malaysia.

Consumers International in recent times has been lobbying for the extension of consumer rights in the revision to the UNGCP that was adopted by a resolution of the General Assembly on 22 December 2015 (UN 2015). CI worked towards a range of new recommendations in the guidelines to adapt them to the globally networked age, including recommendations on digital issues, financial services, privacy, irresponsible marketing and access to knowledge.

\section{Global regulation or laissez faire?}

In many respects, the consumer movement was in the vanguard of those who recognised the importance of cooperation between nations to ensure that consumer protection was placed on the agenda of those bodies that emerged from the umbrella of the United Nations to set the global agenda for the way in which regulation and harmonisation of approaches to food, health, standards and trade, among others, would develop.

It is fair to say that, from time to time, Australia has played a major role in some of these intergovernmental forums. Unfortunately, there has only been one international intergovernmental forum, outside the European Community, dealing with consumer policy: the Consumer Policy Committee of the Organisation for Economic Co-operation and Development. However, while it has been quite influential in shaping policy debates on such matters as financial services, distance selling and e-commerce, as a forum, it does not include the majority of nation-states. 


\section{Deregulation, privatisation and fair trading}

The late 1980switnessed a significant realignment of government priorities away from regulatory activity to a focus on economic enterprise, as the philosophy of economic 'rationalists' gained the ascendancy. Regulatory impact statements, requiring a thorough assessment of the effects of a proposal on those to be regulated, became universal requirements. Adam Smith's dictums on the subject of consumer sovereignty were erased from the memory banks and government 'Consumer Affairs' agencies became known as 'Fair Trading Departments'. Where, in the past, they had been either standalone bodies or part of the 'neutral' legal portfolio, most were gradually absorbed into business or industry portfolios where the consumer affairs function was very much the junior interest. Following the 1998 Australian federal election, for the first time in 25 years, there was no minister with 'Consumer Affairs' in their title, and the consumer affairs policy division was absorbed into the Treasury.

As is so often the case, however, the end of the century saw a turn of the wheel. Public reaction to the poor consumer behaviour of many privatised utilities throughout the world has had the effect of governments considering, or actually, stepping up regulation again.

\section{National uniformity}

The lack of uniformity between the laws of the states and territories has been one of the longest running 'comic' serials in Australia. In the food sector, for example, the first mention of the need for uniformity occurs as early as 1852 in comments attributed to Sir Henry Parkes.

As the realisation that Australia was increasingly competing in an international marketplace gradually dawned on policymakers, efforts to achieve uniformity in the field of consumer protection were stepped up.

From 1984 onwards, but especially up to 1993, there was a rapid acceleration in efforts made by the federal, state and territory consumer affairs ministers through their regular meetings ${ }^{7}$ to achieve

7 Initially called SCOCAM (Standing Committee of Consumer Affairs Ministers) and later renamed MCCA (Ministerial Council on Consumer Affairs). 
uniformity across the raft of consumer legislation. Much of the effort concentrated on replicating the provisions of the TPA in state and territory legislation. Starting with the provisions in Division 1 of Part $V$ of the TPA, dealing with unfair practices, it moved through provisions dealing with post-sale consumer protection; Division 1A dealing with product safety and recalls; and then on to uniform consumer credit legislation; compensation for the failure of travel companies; and trade measurement. In the early 1990s, the charge to deregulation saw a further round of reform through agreement between governments on the need for mutual recognition of each other's schemes for regulation of goods and services generally. In effect, with a few exceptions, this meant states and territories had to recognise schemes for occupational licensing and standards for various products and services, even if these had lower standards than their own. ${ }^{8}$

Similarly, following the achievement of closer economic relations with New Zealand, the two countries agreed on a similar scheme of mutual recognition that was entrenched in nationally uniform legislation. ${ }^{9}$

Finally, on 1 January 2011, the Australian Consumer Law (ACL) commenced.

The ACL includes:

- a national unfair contract terms law covering standard form consumer contracts

- a national law guaranteeing consumer rights when buying goods and services

- a national product safety law and enforcement system

- a national law for unsolicited consumer agreements covering doorto-door sales and telephone sales

- simple national rules for lay-by agreements

- new penalties, enforcement powers and consumer redress options.

8 See, for example, Mutual Recognition Act 1992 (Cth) and Mutual Recognition (Australian Capital Territory) Act 1992.

9 See, for example, Trans-Tasman Mutual Recognition Act 1997 (Cth) and Trans-Tasman Mutual Recognition (South Australia) Act 1999. 
The ACL applies nationally and in all states and territories, and to all Australian businesses. For transactions that occurred prior to 1 January 2011, the previous national, state and territory consumer laws continue to apply.

The full details of the ACL are contained in the Competition and Consumer Act 2010 (Cth), replacing the Trade Practices Act.

\section{The advent of the industry ombudsmen}

With the obvious failure of sole self-regulatory schemes, new co-regulatory mechanisms started appearing. The emergence of industry-based dispute-resolution schemes took place in the late 1980s (with the United Kingdom at the fore, initiating both the insurance and the banking ombudsman schemes). These were a reflection of consumer, government and (some) industry concern that there was a considerable imbalance in the relative bargaining position of the parties when it came to resolving complaints. Previously, affected consumers had to either take a dispute to court or rely on a consumer protection or fair trading agency to take up the matter as a breach of relevant laws. The court option was prohibitively expensive and consumer protection bodies simply did not have the resources to pursue other than a fraction of complaints. Besides, many of the complaints related to service quality and information that were not covered by any statute. The emphasis, when action was taken, was, thus, on prosecution rather than consumer redress and compensation.

Consumer activism and media interest exposed large numbers of unsatisfactory and unacceptable practices in various industries. These ranged from incomprehensible contract terms through to failure to respond to complaints and repair mistakes or, indeed, to provide any relevant information to bewildered consumers.

Initially, the focus was on the financial services sector, but utilities rapidly came in for the same sort of scrutiny. This was accelerated in various countries with the privatisation of previously state-owned monopolies. Other sectors that attracted attention and various external disputeresolution (EDR) systems included real estate agents, funeral directors, legal services, public and private health services, and so on. 
Until recently, with the exception of Scandinavia, where there is a range of consumer complaints boards with a general remit and consumer ombudsmen for particular sectors, the development of these forms of EDR schemes has been concentrated in English-speaking Commonwealth countries.

In Australia, there has been an evolution of the various schemes with, for example, a number of financial services schemes joining together to form the Financial Ombudsman Service, and with the rationalisation of governance in some schemes.

\section{External dispute-resolution principles}

The first external schemes began with the Australian Banking Industry Ombudsman in 1990; the Claims Review Panel (general insurance) and the Life Insurance Complaints Service in 1991; and the Telecommunications Industry Ombudsman in 1993. All schemes, however, still left much to be desired.

Thus it was that work first commenced on the development of principles that should be the basis against which industry dispute-resolution schemes should be measured. They emerged in 1997 as the 'Benchmarks for Industry-based Customer Dispute Resolution Schemes', and set out a series of recommended principles, purposes and key practices. The principles were:

1. Accessibility: The scheme makes itself readily available to customers by promoting knowledge of its existence, being easy to use and having no cost barriers.

2. Independence: The decision-making process and administration of the scheme are independent from scheme members.

3. Fairness: The scheme produces decisions that are fair and seen to be fair by observing the principles of procedural fairness, by making decisions on the information before it and by having specific criteria on which its decisions are based.

4. Accountability: The scheme publicly accounts for its operations by publishing its determinations and information about complaints and highlights any systemic industry problems. 
5. Efficiency: The scheme operates efficiently by keeping track of complaints, ensuring complaints are dealt with by the appropriate process or forum and regularly reviewing its performance.

6. Effectiveness: The scheme is effective by having appropriate and comprehensive terms of reference and periodic independent reviews of its performance.

These benchmarks are now in wide use in both Australia and New Zealand and have played a key role in the examination and review of EDR schemes. In addition, they are prescribed by the Australian Securities and Investments Commission (ASIC), in Regulatory Guide 139, as criteria that must be met by any EDR scheme seeking approval in the financial services sector.

\section{Conclusion}

Consumer protection has advanced as the middle class has prospered around the world. With increased disposable income has come increased market and political power. The product of networked activism, together with effective compliance and enforcement by strong institutions such as the Australian Competition and Consumer Commission (ACCC) - based on well-designed statute law- has been a well-regulated and efficient market (see also, Maher, Chapter 39, this volume). But principles-based regulation has also played a major role, as evidenced in the outcomes achieved by, for example, industry-based dispute-resolution schemes such as the Telecommunications Industry Ombudsman or the Financial Ombudsman Service. In the end, one of the principal reasons consumer protection regulation has predominantly been a success is that, when such regulation is effectively articulated and enforced, everyone wins: consumers, because of the protection of quality and safety of products and services, and business, because of increased consumer trust. 


\section{References}

Goldring, JL and Maher, LW 1976. Consumer Protection Law in Australia. Sydney: Butterworths.

Johns, CHW 1987 [1904]. Babylonian and Assyrian Laws, Contracts and Letters. New York: The Legal Classics Library, Division of Gryphon Editions.

Moloney, JT 1962. Final Report of the Committee on Consumer Protection (Cmnd 1781). London: HMSO.

NSW Department of Consumer Affairs 1987. 200 Years of Consumer Protection in New South Wales. Sydney: Government Printer.

Smith, A 1776. An Inquiry into the Nature and Causes of the Wealth of Nations. London: W Strahan. doi.org/10.1093/oseo/ instance.00043218.

United Nations (UN) 1985. Consumer protection, UN General Assembly Resolution 39/248, 16 April, UN General Assembly, New York.

United Nations (UN) 2015. Consumer protection, UN General Assembly Resolution 70/186, 22 December, UN General Assembly, New York. 
This text is taken from Regulatory Theory: Foundations and applications, edited by Peter Drahos, published 2017 by ANU Press, The Australian National University, Canberra, Australia. 